Supporting Information

\title{
Ligand Switching Ion Chemistry: An SIFDT Case Study of the Primary and Secondary Reactions of Protonated Acetic Acid Hydrates with Acetone
}

\author{
Anatolii Spesyvyi*1, Michal Lacko ${ }^{1,2}$, Kseniya Dryahina ${ }^{1}$, David Smith ${ }^{1}$, Patrik Španěl ${ }^{1}$ \\ ${ }^{1}$ J. Heyrovský Institute of Physical Chemistry of the Czech Academy of Sciences, Dolejškova 2155/3, 18223 \\ Prague 8, Czech Republic \\ ${ }^{2}$ Charles University, Faculty of Mathematics and Physics, V Holešovičkách 747/2, 18000 Prague 8, Czech \\ Republic
}

Corresponding author: Anatolii Spesyvyi, J. Heyrovský Institute of Physical Chemistry of the Czech Academy of Sciences, Dolejškova 3, Prague 8, 18223, Czech Republic, +420 266052112

Email: anatolii.spesyvyi@jh-inst.cas.cz 

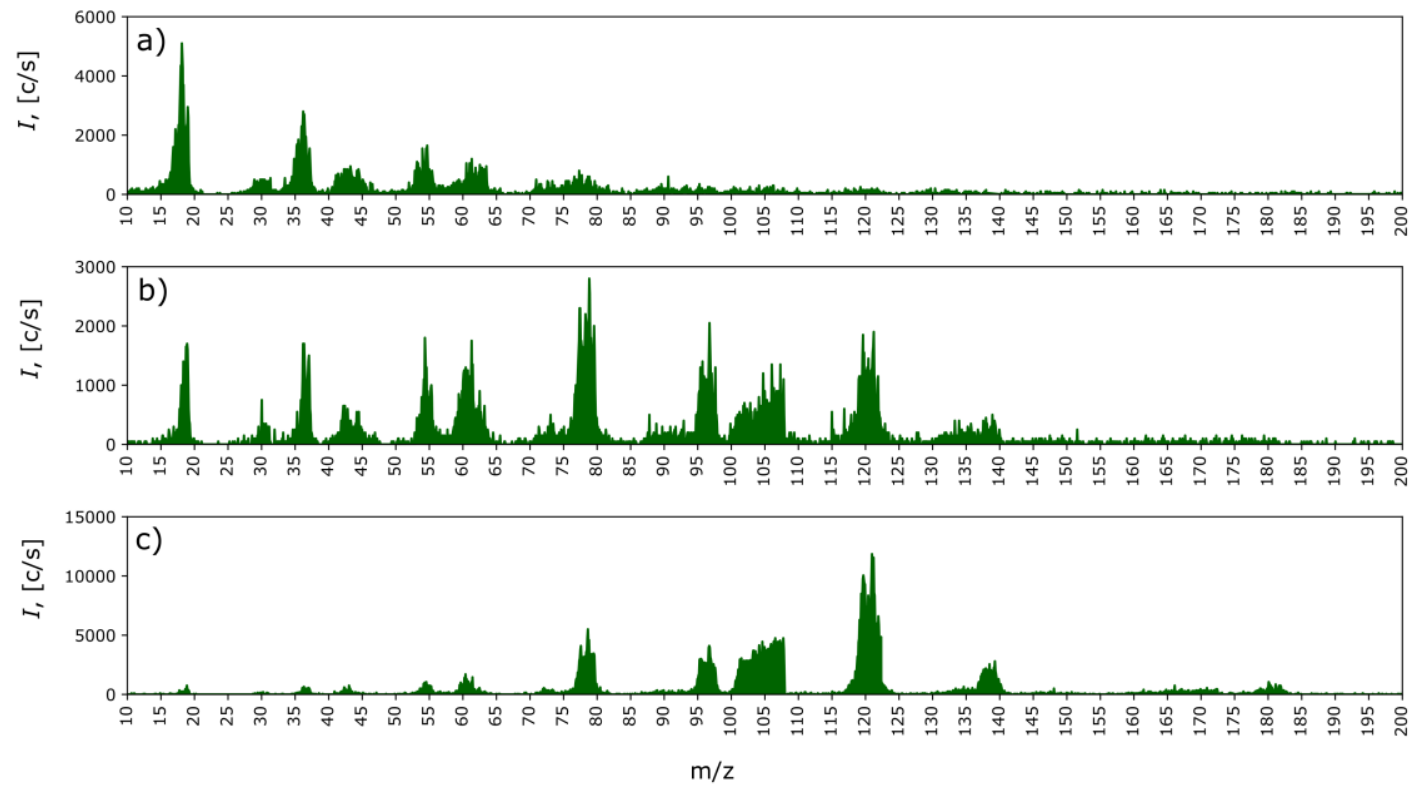

Figure S1. Mass spectra scans by QMF demonstrating ion composition after OP at different abundances of introduced acetic acid/water vapour in OP chamber: valve is closed (a), small amount (b) and valve fully open (c). It can be noticed that ions shift from $\mathrm{H}_{3} \mathrm{O}^{+}\left(\mathrm{H}_{2} \mathrm{O}\right)_{n}$ to protonated acetic acid hydrates and protonated acetic acid dimer. The signal in the region $\mathrm{m} / \mathrm{z} 100-108$ is likely an instrumental artefact.
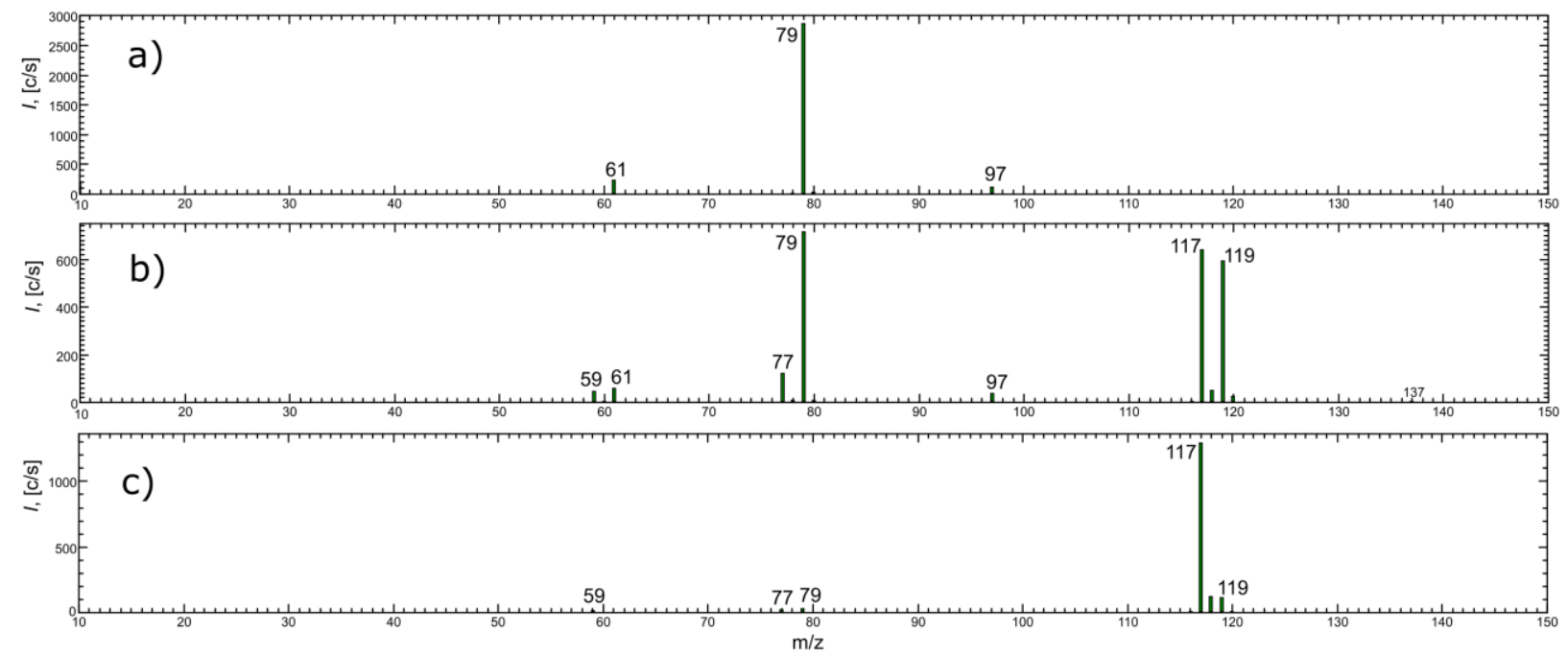

Figure S2. Mass spectral scans by QMA showing ion distributions in the DTR when $m / z \quad 97$ is filtered by QMF and injected at different abundances of acetone into the DTR: a) no acetone; b) small amount; c) maximum amount. 

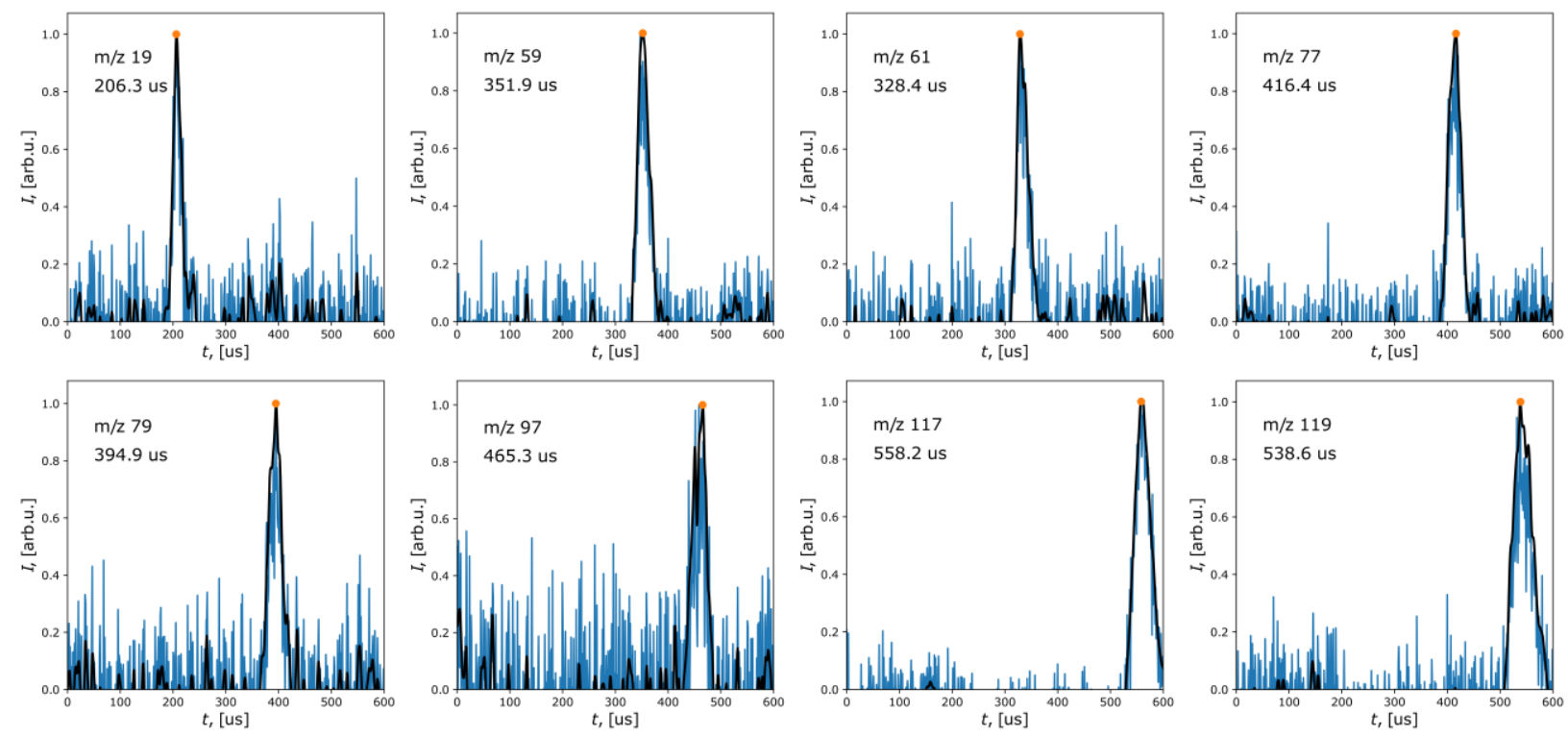

Figure S3. Arrival time distributions of the studied ions obtained using the Hadamard modulation on GM before the DTR.
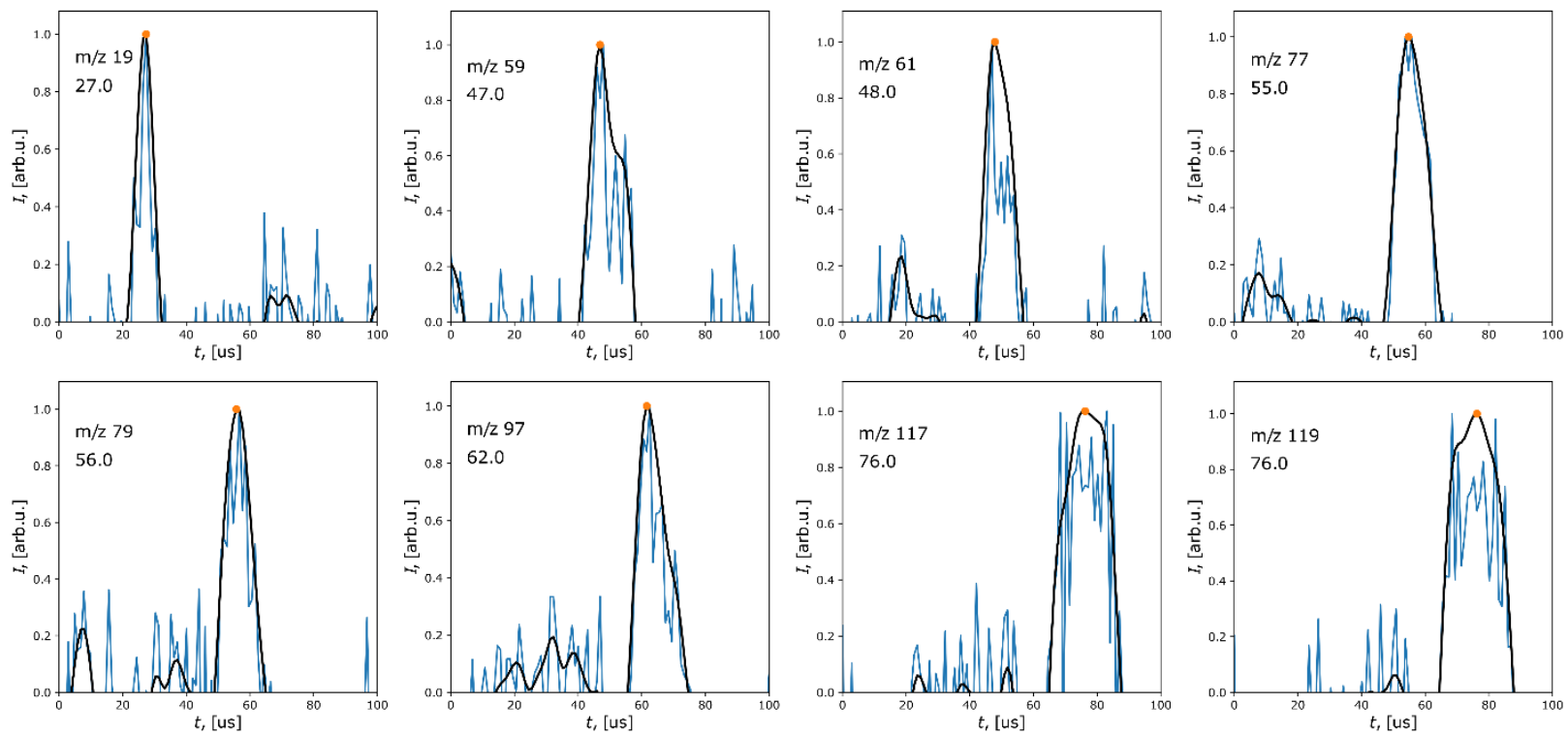

Figure S4. Arrival time distributions of the studied ions obtained using the Hadamard modulation on SNC before the QMA. 

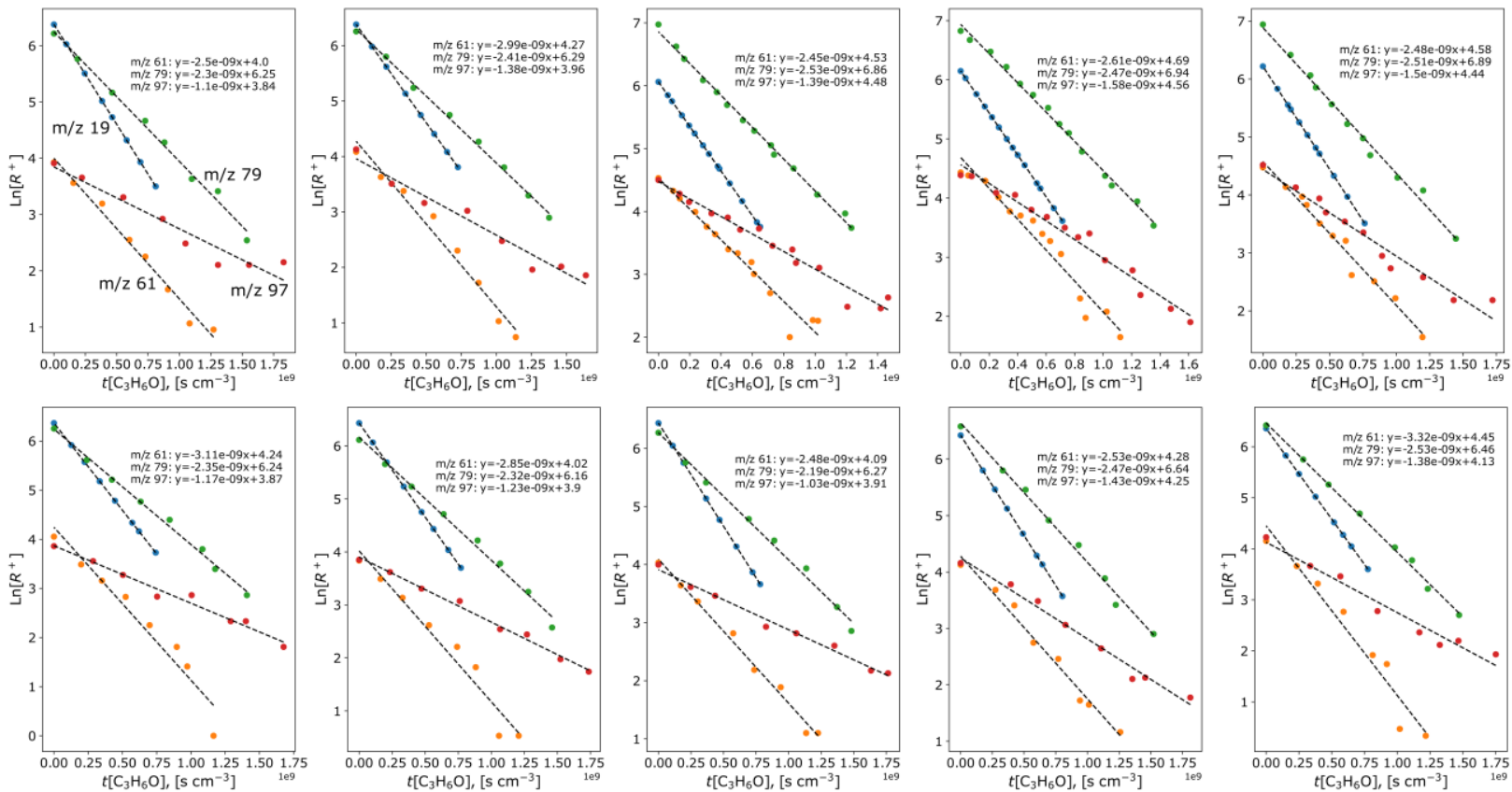

Figure S5. Semi logarithmic decay plots used to estimate the reaction rate coefficients for $m / z 61, m / z 79$ and $m / z 97$ with acetone.
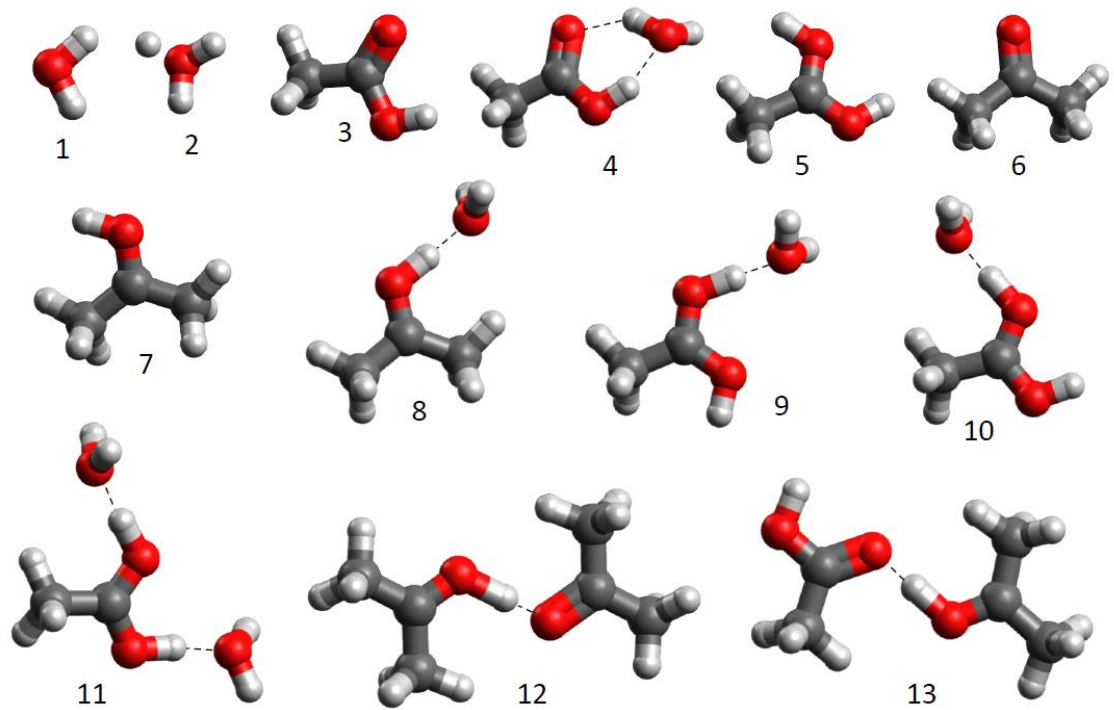

Figure S6. Geometries of ions and molecules from the DFT optimizations used to calculate the reaction thermochemistry: $\mathrm{H}_{2} \mathrm{O}$ (1), $\mathrm{H}_{3} \mathrm{O}^{+}(2), \mathrm{C}_{2} \mathrm{H}_{4} \mathrm{O}_{2}$ (3), $\mathrm{C}_{2} \mathrm{H}_{4} \mathrm{O}_{2}$ ( $\left.\mathrm{H} 2 \mathrm{O}\right)(4), \mathrm{C}_{2} \mathrm{H}_{4} \mathrm{O}_{2} \mathrm{H}^{+}$(5), $\mathrm{C}_{3} \mathrm{H}_{6} \mathrm{O}$ (6), $\mathrm{C}_{3} \mathrm{H}_{6} \mathrm{OH}^{+}$(7), $\mathrm{C}_{3} \mathrm{H}_{6} \mathrm{OH}^{+}\left(\mathrm{H}_{2} \mathrm{O}\right)(8), \mathrm{C}_{2} \mathrm{H}_{4} \mathrm{O}_{2} \mathrm{H}^{+}\left(\mathrm{H}_{2} \mathrm{O}\right)(9,10), \mathrm{C}_{2} \mathrm{H}_{4} \mathrm{O}_{2} \mathrm{H}^{+}\left(\mathrm{H}_{2} \mathrm{O}\right)_{2}(11), \mathrm{C}_{2} \mathrm{H}_{4} \mathrm{O}_{2} \mathrm{H}^{+}\left(\mathrm{C}_{3} \mathrm{H}_{6} \mathrm{O}\right)(12), \mathrm{C}_{3} \mathrm{H}_{6} \mathrm{OH}^{+}\left(\mathrm{C}_{3} \mathrm{H}_{6} \mathrm{O}\right)$ (13). 


\section{Reaction kinetics modelling}

The numerical modelling of the proposed ion chemistry was based on the experimental data of relative ion intensities obtained for increasing acetone concentration (Fig. 5 in the paper). It is important to note that the secondary reactions with water molecules were not included as the experiment was done in dry helium buffer gas.

Firstly, we have optimized the decay of the three primary ions - protonated acetic acid $(\mathrm{m} / \mathrm{z} 61)$, hydrated protonated acetic acid $(\mathrm{m} / \mathrm{z}$ 79) and dihydrated protonated acetic acid $(\mathrm{m} / \mathrm{z}$ 97) - based on the experimental determination of the total reaction rates (Table 1 in the paper). Initial concentrations (in $\left.\mathrm{cm}^{-3}\right)$ of reagent ions were set to be 5E2, 8E3 and 5E2 for protonated acetic acid $(\mathrm{m} / z$ 61), hydrated protonated acetic acid $(\mathrm{m} / \mathrm{z} 79)$ and dihydrated protonated acetic acid ( $\mathrm{m} / \mathrm{z}$ 97), respectively, to correspond with the ion count rate observed at zero acetone concentration. Total reaction rates of regent ions were than optimized to fit the experimental data. (see Fig. S7) The optimized values of the total reaction rates were used for further simulations.

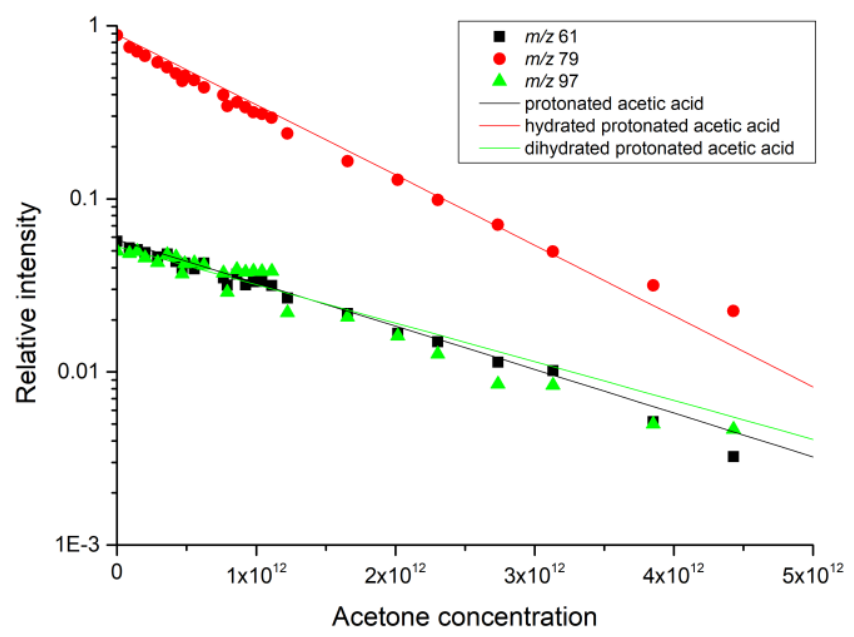

Figure S7. A model of relative reagent ions intensities as functions of the acetone concentration. The optimized total reaction rate coefficients are 2.1, 2.9 and $1.3\left(\right.$ all in $10^{-9} \mathrm{~cm}^{3} \mathrm{~s}^{-1}$ ) for protonated acetic acid, hydrated protonated acetic acid and dihydrated protonated acetic acid, respectively, reacting with acetone. Presented data are relative to all ions involved in the simulation or experimental data set.

\section{Simulations of protonated acetone channel}

Protonated acetone is primarily formed via proton transfer between protonated acetic acid and acetone. The theoretical calculations, however, suggest that protonated acetic acid can also react via three body reaction with carrier gas forming $\mathrm{CH}_{3} \mathrm{COOHH}^{+} \mathrm{CH}_{3} \mathrm{COCH}_{3}$ ion with $\mathrm{m} / z$ 119. Finally, protonated acetone in secondary reaction with acetone forms protonated acetone dimer with $m / z 117$, with experimentally determined binary reaction rate coefficient $1.5 \times 10^{-9} \mathrm{~cm}^{3} \mathrm{~s}^{-1}$. The simulation presented in Fig. S8 (left) shows that the formation of protonated acetone cannot be explained only by proton transfer reaction of protonated acetic acid as this reaction alone underestimate the detected abundance of protonated acetone ions. Thus, we supplemented the formation of protonated acetone by additional channel: 


\section{$\mathrm{CH}_{3} \mathrm{COOH}^{+} . \mathrm{H}_{2} \mathrm{O}+\mathrm{CH}_{3} \mathrm{COCH}_{3} \rightarrow \mathrm{CH}_{3} \mathrm{COCH}_{3} \mathrm{H}^{+}+\mathrm{CH}_{3} \mathrm{COOH} . \mathrm{H}_{2} \mathrm{O}$}

This reaction is in theoretical calculation slightly endergonic, however only small reaction rate $\left(1 \times 10^{-10}\right.$ $\mathrm{cm}^{3} \mathrm{~s}^{-1}$ ) is required to fit the observed formation of protonated acetone.

The theoretical calculation also suggests the protonated acetic acid can react with acetone by a threebody reaction with helium carrier gas, forming the mixed proton-bound dimer with $m / z 119$. This process has a minor effect on formation of the mixed proton-bound dimer with $m / z 119$, as this ion is effectively produced by other channels discussed later. To investigate the effect of this channel, we used two different reaction rates, 0.22 and $2.15, \times 10^{-26} \mathrm{~cm}^{6} \mathrm{~s}^{-1}$, representing the bimolecular reaction rates 0.1 and $1,10^{-9} \mathrm{~cm}^{3} \mathrm{~s}^{-1}$. The lower value of reaction rate does not significantly affect the proposed reaction schema. The higher value of reaction rate requires enhancement of the hydrated protonated acetic acid reactivity producing protonated acetone.
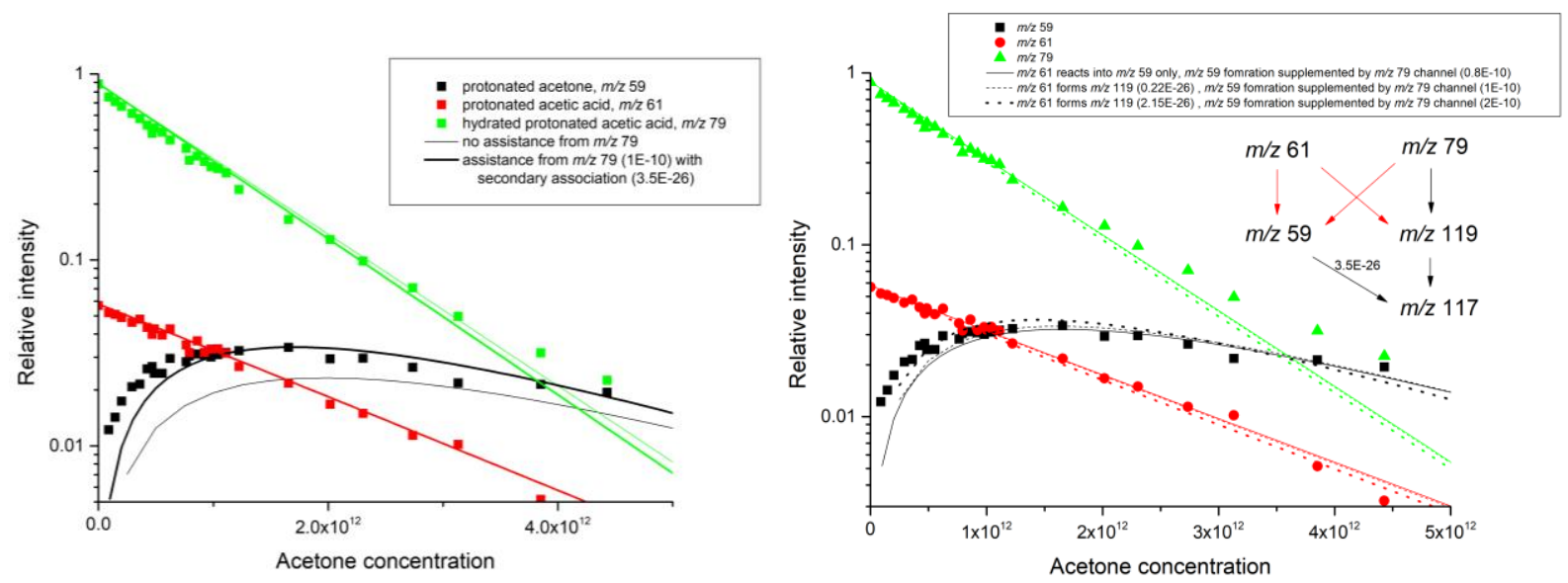

Figure S8. Modelling of the protonated acetone channel. Left in thin line is the formation of protonated acetone only from protonated acetic acid at its full reactivity, $2.9 \times 10^{-9} \mathrm{~cm}^{3} \mathrm{~s}^{-1}$, supplemented by a secondary reaction with acetone, forming protonated acetone dimers at $3.22 \times 10^{-26} \mathrm{~cm}^{6} \mathrm{~s}^{-1}$ (corresponding to a bimolecular reaction rate $\left.1.5 \times 10^{-9} \mathrm{~cm}^{3} \mathrm{~s}^{-1}\right)$. The thick line indicates the protonated acetone also produced from hydrated protonated acetic acid via reaction with acetone at $1 \times 10^{-10} \mathrm{~cm}^{3} \mathrm{~s}^{-1}$. Reaction rate for the secondary reaction of protonated acetone forming protonated acetone dimer was slightly increased to $3.5 \times 10^{-26} \mathrm{~cm}^{6} \mathrm{~s}^{-1}$. On the right side we additionally added tree body reaction of protonated acetic acid and acetone forming the mixed proton-bound dimer with $m / z 119$. Two reaction rates to this channel were considered: 0.22 and $2.15, \times 10^{-26} \mathrm{~cm}^{-6} \mathrm{~s}^{-1}$, representing the bimolecular reaction rates 0.1 and $1 \times 10^{-9} \mathrm{~cm}^{3} \mathrm{~s}^{-1}$. Presence of this channel requires higher reaction rate of hydrated protonated acetic acid forming protonated acetone to maintain the level of observed protonated acetone.

\section{Simulation of the main reaction channels}

The main reaction channels in the simulation are those initiated by the reaction of hydrated protonated acetic acid with acetone, producing hydrated protonated acetone with $\mathrm{m} / \mathrm{z} 77$ and the mixed protonbound dimer with $m / z 119$, followed by the secondary reactions generating protonated acetone dimer 
with $\mathrm{m} / \mathrm{z}$ 117. Considering the theoretical calculations and the experimentally obtained reaction rates for $m / z 77$ and $m / z 119$ ions, we proposed following reaction schemas that could represent the observed data.

RS1. Direct formation of $m / z 77$ and $m / z 119$ ions. Both ions are formed directly via bimolecular reaction of hydrated protonated acetic acid with acetone.

RS2. Formation via stable $m / z 137$ intermediate. Reaction of hydrated protonated acetic acid with acetone result into formation of stable $\mathrm{m} / \mathrm{z} 137$ ion that may spontaneously (or by collisions with carrier gas) dissociate into $\mathrm{m} / \mathrm{z} 77$ and $\mathrm{m} / \mathrm{z} 119$ ions.

RS3. Formation via quasi-stable $\mathrm{m} / \mathrm{z} 137$ intermediate. Reaction of hydrated protonated acetic acid with acetone result into formation of quasi-stable $\mathrm{m} / z 137$ intermediate, that may spontaneously dissociate into $m / z 77$ and $m / z 119$ ions or be stabilised by collisions with helium carrier gas into stable $m / z 137$ ion.

For the first reaction scenario (RS1), a direct formation of $m / z 77$ and $m / z 119$ ions, we assume that both ions are formed rapidly via reaction (7). The proposed simulation is shown in Fig. S9, using reaction rates $0.3 \times 10^{-9} \mathrm{~cm}^{3} \mathrm{~s}^{-1}$ and $2.5 \times 10^{-9} \mathrm{~cm}^{3} \mathrm{~s}^{-1}$ for generation of hydrated protonated acetone $(\mathrm{m} / \mathrm{z} 77)$ and the mixed proton-bound dimer $(\mathrm{m} / \mathrm{z} 119)$, respectively. The secondary reaction rate coefficients for both ions with acetone have been experimentally estimated as $1.8 \times 10^{-9} \mathrm{~cm}^{3} \mathrm{~s}^{-1}$ and $1.2 \times 10^{-9} \mathrm{~cm}^{3} \mathrm{~s}^{-1}$, respectively. However, in the simulation the secondary reaction of the mixed proton-bound $\operatorname{dimer}(\mathrm{m} / z \mathrm{119})$ had to be increased up to $1.8 \times 10^{-9} \mathrm{~cm}^{3} \mathrm{~s}^{-1}$ to follow the abundance of $\mathrm{m} / \mathrm{z} 117$ and $\mathrm{m} / \mathrm{z} 119$.

The formation of the hydrated mixed proton-bound dimer $(\mathrm{m} / \mathrm{z} 137)$ is provided via the following reaction channels: $a$, by reaction of dihydrated protonated acetic acid with acetone and $b$, by three body reaction of hydrated protonated acid with acetone stabilised by helium. In the first scenario, we assume formation of $\mathrm{m} / \mathrm{z} 137$ at variation of low reaction rates, up to $2.5 \times 10^{-10} \mathrm{~cm}^{3} \mathrm{~s}^{-1}$ for ligand switching reaction of dihydrated protonated acetic acid with acetone and up to $5 \times 10^{-28} \mathrm{~cm}^{6} \mathrm{~s}^{-1}$ for three-body association of hydrated protonated acetic acid with acetone. This scenario represents the observed profile of $\mathrm{m} / \mathrm{z} 137$ well, assuming the ion undergo a secondary reaction with acetone at reaction rate $2 \times 10^{-9} \mathrm{~cm}^{3} \mathrm{~s}^{-1}$. The product of this secondary reaction can be the mixed proton-bound dimer $(\mathrm{m} / \mathrm{z} 119)$ or the protonated acetone dimer $(\mathrm{m} / \mathrm{z}$ 117). The profile of either presented product ion is not highly affected as the abundance of the $m / z 137$ is very low. The reaction of ion with $m / z 137$ with acetone is necessary as the spontaneous dissociation, triggered for example by collisions with neutrals, does not represent the observed profile well (see the red line in Fig. S10, left). Note that due to low reaction rate of dihydrated protonated acetic acid $(\mathrm{m} / \mathrm{z}$ 97) with acetone forming the hydrated mixed proton-bound dimer $(\mathrm{m} / \mathrm{z} 137)$, another reaction with acetone, leading into formation of the mixed proton-bound $\operatorname{dimer}(\mathrm{m} / \mathrm{z} 119)$, was use to maintain its total reactivity.

In the second scenario, the three-body reaction of hydrated protonated acetic acid with acetone stabilised by helium remained at the previous level, to $3 \times 10^{-28} \mathrm{~cm}^{6} \mathrm{~s}^{-1}$, however we assume the second channel of dihydrated protonated acetic acid reacting with acetone leads only to formation of $m / z 137$. In this scenario, the formed ion with $\mathrm{m} / \mathrm{z} 137$ cannot react by secondary reaction with acetone, as the reaction rate of such reaction would be unrealistically high. Thus, we assume it may be consumed only via monomolecular self-dissociation process, triggered by collision with gas or other neutrals: $m / z 137->m / z 119$ $+\mathrm{H}_{2} \mathrm{O}$. The model profiles (see Fig .S10, right) correspond to the experimental data using the reaction rate $20000 \mathrm{~s}^{-1}$. 
Due to low abundance of the $m / z 137$ ion, it is difficult to favour either scenario as both can be used to describe the formation of $m / z 137$.

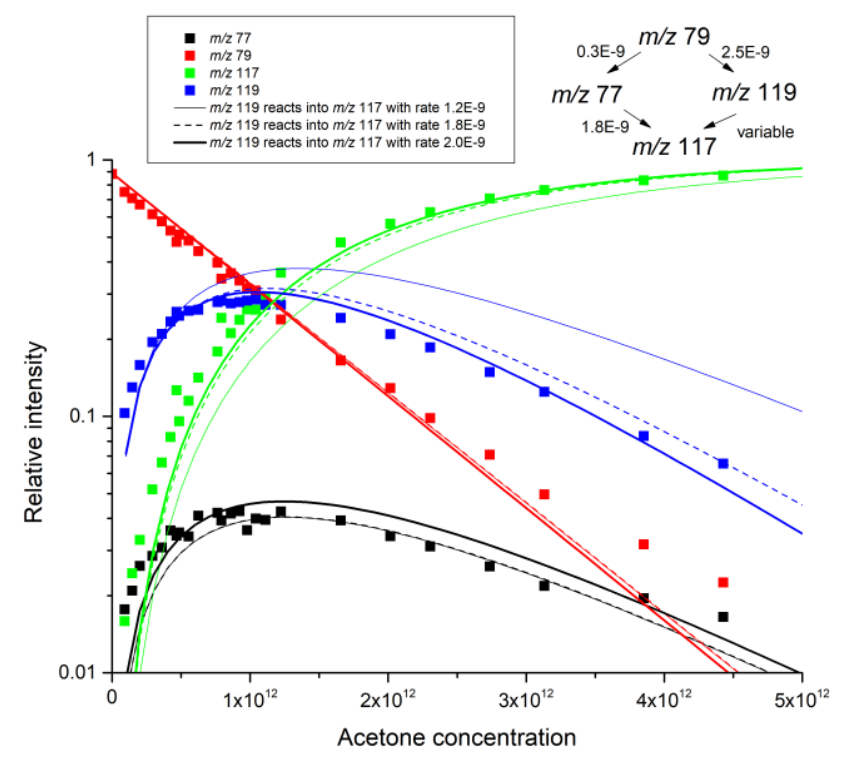

Figure S9. Modelling of the main reaction channel for hydrated protonated acetone $(\mathrm{m} / \mathrm{z} 77)$ and the mixed proton-bound dimer $(\mathrm{m} / \mathrm{z} 119)$ via direct formation from hydrated protonated acetic acid $(\mathrm{m} / \mathrm{z} 79)$. The total reactivity of hydrated protonated acetic acid is reduced to $2.8 \times 10^{-9} \mathrm{~cm}^{3} \mathrm{~s}^{-1}$ due to another reaction forming $\mathrm{m} / z 137$ ion described later. The selected rate coefficients $0.3 \times 10^{-9} \mathrm{~cm}^{3} \mathrm{~s}^{-1}$ and $2.5 \times 10^{-9}$ $\mathrm{cm}^{3} \mathrm{~s}^{-1}$ well describe the generation of hydrated protonated acetone $(\mathrm{m} / z \mathrm{z7})$ and the mixed proton-bound $\operatorname{dimer}(\mathrm{m} / \mathrm{z}$ 119). Both ions further react with acetone, forming protonated acetone dimer $(\mathrm{m} / \mathrm{z} 117)$ what is the ultimate product of the reaction sequence. The experimentally obtained reaction rate for the secondary reaction of the mixed proton-bound dimer $(\mathrm{m} / z \mathrm{119})$, determined as $1.2 \times 10^{-9} \mathrm{~cm}^{3} \mathrm{~s}^{-1}$ needs to be increased up to $1.8 \times 10^{-9} \mathrm{~cm}^{3} \mathrm{~s}^{-1}$ in order to interpolate observed data. 

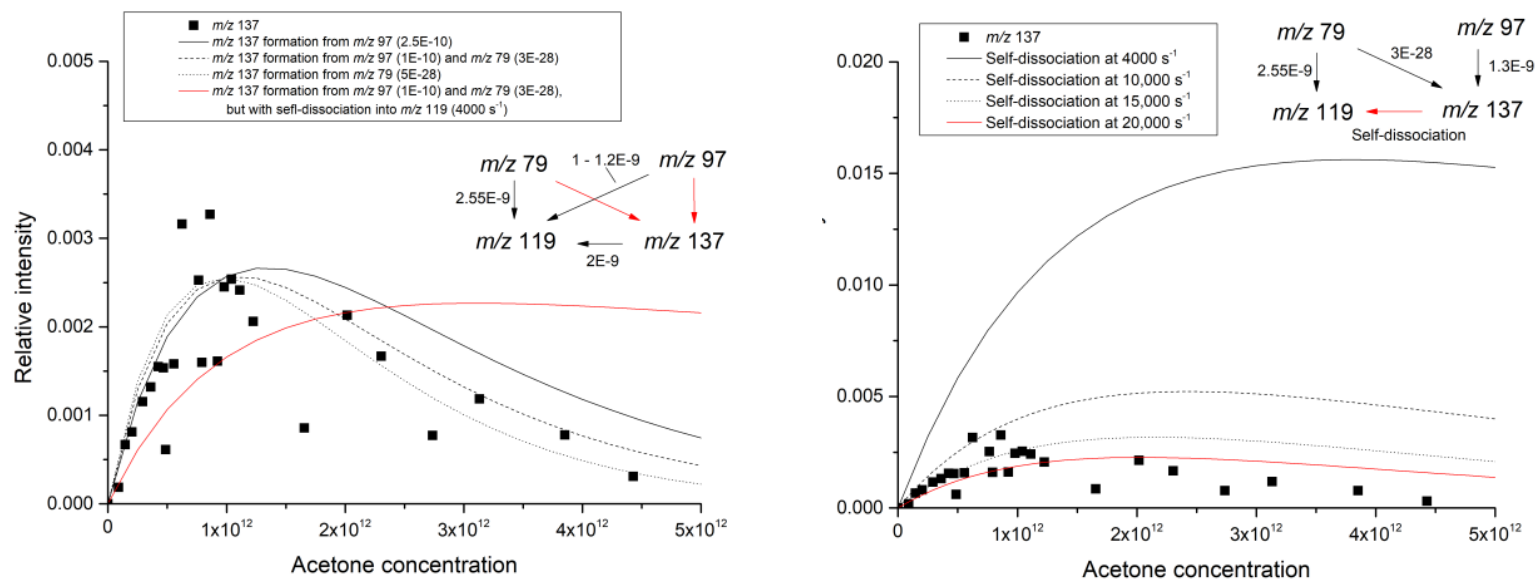

Figure S10. Simulation of the hydrated mixed proton-bound dimer $(m / z 137)$. Left, using a variation of low reaction rates of $\mathrm{m} / \mathrm{z} 79$ and $\mathrm{m} / \mathrm{z} 97$ with acetone. The hydrated mixed proton-bound dimer may then react with acetone into $m / z 119$ or $m / z 117$ (due to low abundance of $m / z 137$, both products are possible). In red line, the secondary reaction is replaced by self-dissociation channel, not requiring acetone to react with $m / z$ 137. Right, for the higher reaction rates. The rate coefficient for ligand switching reaction of dihydrated protonated acetic acid with acetone is significantly increased to $1.3 \times 10^{-9} \mathrm{~cm}^{3} \mathrm{~s}^{-1}$. We do not assume the $m / z 137$ ion secondary reaction with acetone, as those would need to be unrealistically fast. Instead, we simulated mono-molecular self-dissociation process, triggered by collision with gas or other neutrals: $m / z 137->m / z 119+\mathrm{H}_{2} \mathrm{O}$.

For the second reaction scenario (RS2) we assume the reaction of hydrated protonated acetic acid with acetone results into formation of stable $\mathrm{m} / \mathrm{z} 137$ ion that may spontaneously (or by collisions with carrier gas) dissociate into $\mathrm{m} / \mathrm{z} 77$ and $\mathrm{m} / \mathrm{z} 119$ ions. Those ions will, as in the previous simulation, react in a secondary reaction with acetone, forming protonated acetone dimer $(m / z 117)$. In the present setup (see Fig. S11), intermediate ion $(\mathrm{m} / \mathrm{z} 137)$ is formed rapidly from three-body association of hydrated protonated acetic acid $(\mathrm{m} / z \mathrm{79})$ with acetone and helium at reaction rate $6 \times 10^{-26} \mathrm{~cm}^{6} \mathrm{~s}^{-1}$ and also from a ligand switching reaction of dihydrated protonated acetic acid $(\mathrm{m} / \mathrm{z} 97)$ with acetone at reaction rate $1.3 \times 10^{-9} \mathrm{~cm}^{3} \mathrm{~s}^{-1}$. Reaction rate of hydrated protonated acetic acid $(\mathrm{m} / \mathrm{z} 79)$ correspond to the bimolecular reaction rate $2.8 \times 10^{-9} \mathrm{~cm}^{3} \mathrm{~s}^{-1}$. Formed intermediate ion with $\mathrm{m} / \mathrm{z} 137$ than spontaneously dissociate into main fragments hydrated protonated acetone $(\mathrm{m} / \mathrm{z} 77)$ and the mixed proton-bound dimer $(\mathrm{m} / \mathrm{z} 119)$ with reaction rate coefficients $35000 \mathrm{~s}^{-1}$ and $250000 \mathrm{~s}^{-1}$, respectively. Reaction coefficients were optimised to correspond with observed abundance of involved ions: $m / z$ 137, $m / z 77$ and $m / z 119$. Formed hydrated protonated acetone $(\mathrm{m} / \mathrm{z} 77)$ and the mixed proton-bound dimer $(\mathrm{m} / \mathrm{z} 119)$ undergo a secondary reaction with acetone, resulting into the formation of protonated acetone dimer $(\mathrm{m} / \mathrm{z} 117)$. Also in this situation, we initiated the simulation by experimentally obtained values of both secondary reactions. However, the secondary reaction of the mixed proton-bound $\operatorname{dimer}(\mathrm{m} / z \mathrm{119})$ had to be optimised and increased to value $1.8 \times 10^{-9} \mathrm{~cm}^{3} \mathrm{~s}^{-1}$ to reflect the decay of the $\mathrm{m} / z 119$ and the intensity of the $\mathrm{m} / z 117$. 


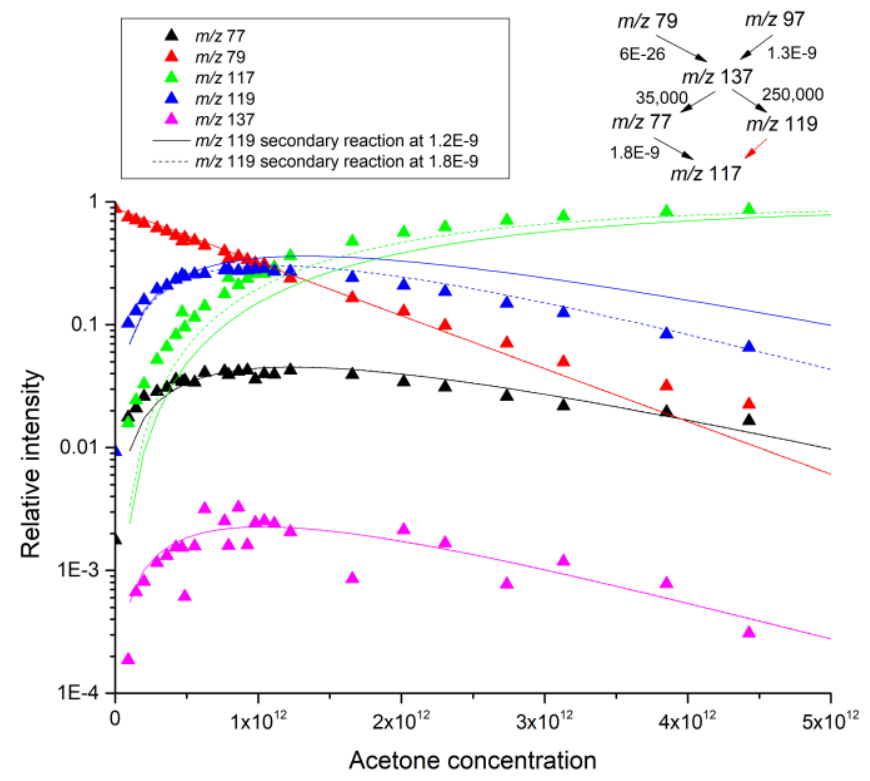

Figure S11. Modelling of the main reaction channel for hydrated protonated acetone $(\mathrm{m} / \mathrm{z} 77)$ and the mixed proton-bound dimer ( $m / z$ 119) via formation of stable intermediate ion with $m / z 137$. In the figure, the two line types represent simulation using different reaction rates for secondary reaction of the mixed proton-bound dimer $(\mathrm{m} / \mathrm{z} 119)$ with acetone, $1.2 \times 10^{-9} \mathrm{~cm}^{3} \mathrm{~s}^{-1}$ (solid line) and $1.8 \times 10^{-9} \mathrm{~cm}^{3} \mathrm{~s}^{-1}$ (dash line).

Finally, for the third reaction scenario (RS3), we considered the similar situation as the one above but the intermediate ion with $\mathrm{m} / \mathrm{z} 137$ was generated in a quasi-stable state, form where it may dissociate into hydrated protonated acetone $(\mathrm{m} / \mathrm{z} 77)$ and the mixed proton-bound dimer $(\mathrm{m} / \mathrm{z} 119)$ or it may stabilise into a stable ion with $\mathrm{m} / \mathrm{z}$ 137. In the Fig. S12 we can compare difference between this and previous situation. Stabilisation of the ion with $\mathrm{m} / \mathrm{z} 137$ would mean it will no more spontaneously dissociate. Thus, the only reaction available is the reaction of $\mathrm{m} / \mathrm{z} 137$ with acetone, forming protonated acetone dimer. As this reaction is unlikely to take place, the abundance of ion with $m / z 137$ will not correspond to the observed profile. 


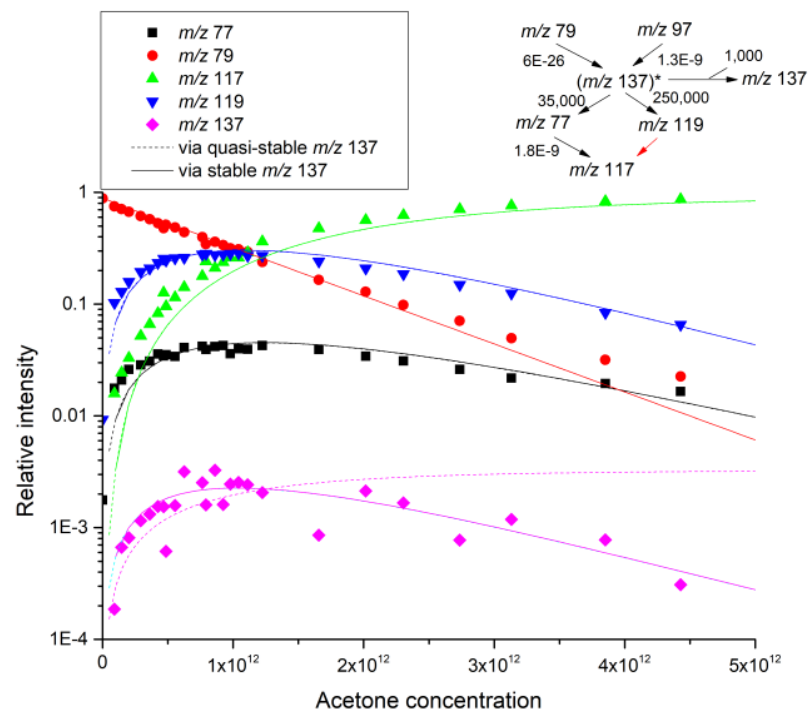

Figure S12. A comparison between formation of stable (solid) and quasi-stable (dashed) intermediate ion with $\mathrm{m} / \mathrm{z}$ 137. Simulated profile of ion with $\mathrm{m} / \mathrm{z} 137$ generated from the quasi-stable ion with $\mathrm{m} / \mathrm{z} 137$ does not correspond with the observed experimental profile. Additional reaction would be required (as in Fig. S10) to bend the tail of the dashed line so it would correspond to the experimental data.

The experimental data can be fitted using two approaches: via a direct formation of hydrated protonated acetone $(\mathrm{m} / \mathrm{z} 77)$ and the mixed proton-bound dimer $(\mathrm{m} / \mathrm{z} 119)$ from reaction of hydrated protonated acetic acid $(\mathrm{m} / \mathrm{z} 79)$ and acetone and also via formation of intermediate ion with $\mathrm{m} / \mathrm{z} 137$ from reaction of hydrated protonated acetic acid $(\mathrm{m} / \mathrm{z} 79)$, which will dissociate into hydrated protonated acetone $(\mathrm{m} / \mathrm{z}$ $77)$ and the mixed proton-bound dimer $(\mathrm{m} / \mathrm{z} 119)$. Both solutions describe the experimental ion profiles well (see Fig. S13). The second situation contains fewer reaction channels as both reagent ions hydrated protonated acetic acid $(\mathrm{m} / \mathrm{z} 79)$ and dihydrated protonated acetic acid $(\mathrm{m} / \mathrm{z}$ 97) react with acetone into $\mathrm{m} / z$ 137. Secondary reactions of both ion products with acetone, hydrated protonated acetone $(\mathrm{m} / z \mathrm{77})$ and the mixed proton-bound dimer $(\mathrm{m} / \mathrm{z} 119)$ occur at reaction rates close to experimental, however, for the mixed proton-bound dimer $(m / z \quad 119)$ the secondary reaction needs to be increased to $1.8 \times 10^{-9}$ $\mathrm{cm}^{3} \mathrm{~s}^{-1}$ to represent the observed formation of protonated acetone dimer ( $\left.\mathrm{m} / z \mathrm{117}\right)$. 


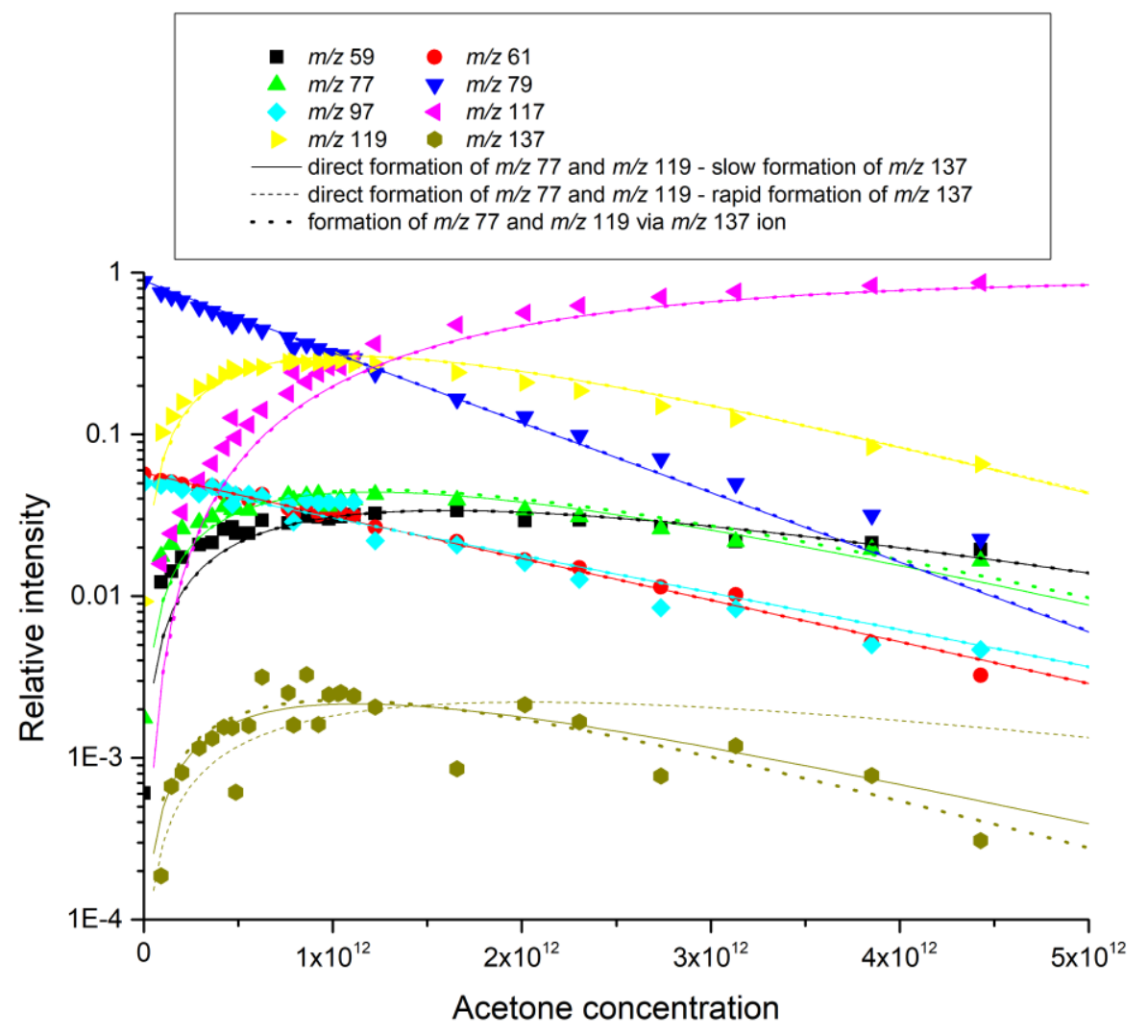

Figure S13. Comparison between individual solutions: Solution 1 - direct formation of $\mathrm{m} / \mathrm{z} 77$ and $\mathrm{m} / \mathrm{z}$ 119 with slow formation of $m / z$ 137, Solution 2 - direct formation of $m / z 77$ and $m / z 119$ with rapid formation of $\mathrm{m} / \mathrm{z} 137$, Solution 3 - formation of $\mathrm{m} / \mathrm{z} 77$ and $\mathrm{m} / \mathrm{z} 119$ via $\mathrm{m} / \mathrm{z} 137$ ion. Details of all solutions are collected in individual logs. 
Model parameters

Table S1. Ions and their properties used in the simulation

\begin{tabular}{|l|l|l|l|l|}
\hline Molecule & $\begin{array}{l}\text { Initial } \\
\text { Concentration } \\
\left(\mathrm{cm}^{-3}\right)\end{array}$ & $\begin{array}{l}\text { Reduced } \\
\text { mobility } \\
\left(\mathrm{cm}^{2} / \mathrm{Vs}\right)\end{array}$ & Mass (Da) & $\begin{array}{l}\text { Diffusion } \\
\text { coefficient } \\
\left(\mathrm{cm}^{2} / \mathrm{s}\right)\end{array}$ \\
\hline $\mathrm{He}$ & $4.67 \mathrm{E}+16$ & 0 & 4.002602 & \\
\hline $\mathrm{C}_{3} \mathrm{H}_{6} \mathrm{O}$ & 0 & 0 & 58.07914 & \\
\hline $\mathrm{C}_{2} \mathrm{H}_{4} \mathrm{O}_{2}\left(\mathrm{H}_{2} \mathrm{O}\right)$ & 0 & 0 & 78.06724 & \\
\hline $\mathrm{C}_{2} \mathrm{H}_{4} \mathrm{O}_{2}$ & 0 & 0 & 60.05196 & \\
\hline $\mathrm{C}_{2} \mathrm{H}_{4} \mathrm{O}_{2} \mathrm{H}^{+}$ & 500 & 13.9 & 61.0599 & 257.07 \\
\hline $\mathrm{C}_{3} \mathrm{H}_{6} \mathrm{OH}^{+} \mathrm{C}_{2} \mathrm{H}_{4} \mathrm{O}_{2}$ & 0 & 8.6 & 119.13904 & 163.48 \\
\hline $\mathrm{C}_{2} \mathrm{H}_{4} \mathrm{O}_{2} \mathrm{H}^{+}\left(\mathrm{H}_{2} \mathrm{O}\right)\left(\mathrm{C}_{3} \mathrm{H}_{6} \mathrm{O}\right)$ & 0 & 8 & 137.15432 & 143.77 \\
\hline $\mathrm{C}_{2} \mathrm{H}_{4} \mathrm{O}_{2} \mathrm{H}^{+}\left(\mathrm{H}_{2} \mathrm{O}\right)_{2}$ & 500 & 9.8 & 97.09046 & 192.13 \\
\hline $\mathrm{C}_{3} \mathrm{H}_{6} \mathrm{OH}^{+}$ & 0 & 12.8 & 59.08708 & 261.66 \\
\hline $\mathrm{C}_{3} \mathrm{H}_{6} \mathrm{OH}^{+}\left(\mathrm{C}_{3} \mathrm{H}_{6} \mathrm{O}\right)$ & 0 & 8.2 & 117.16622 & 165.82 \\
\hline $\mathrm{C}_{3} \mathrm{H}_{6} \mathrm{OH}^{+}\left(\mathrm{H}_{2} \mathrm{O}\right)$ & 0 & 10.9 & 77.10236 & 224.41 \\
\hline $\mathrm{C}_{2} \mathrm{H}_{4} \mathrm{O}_{2} \mathrm{H}^{+}\left(\mathrm{H}_{2} \mathrm{O}\right)$ & 8000 & 11.6 & 79.07518 & 220.87 \\
\hline
\end{tabular}

Table S2. Solution 1 - direct formation of $m / z 77$ and $m / z 119$ with slow formation of $m / z 137$

\begin{tabular}{|c|c|}
\hline Reaction & Rate coefficient \\
\hline $\mathrm{C}_{2} \mathrm{H}_{4} \mathrm{O}_{2} \mathrm{H}^{+}+\mathrm{C}_{3} \mathrm{H}_{6} \mathrm{O} \rightarrow \mathrm{C}_{3} \mathrm{H}_{6} \mathrm{OH}^{+}+\mathrm{C}_{2} \mathrm{H}_{4} \mathrm{O}_{2}$ & $2 \times 10^{-9}$ \\
\hline $\mathrm{C}_{3} \mathrm{H}_{6} \mathrm{OH}^{+}+\mathrm{C}_{3} \mathrm{H}_{6} \mathrm{O}+\mathrm{He} \rightarrow \mathrm{C}_{3} \mathrm{H}_{6} \mathrm{OH}^{+}\left(\mathrm{C}_{3} \mathrm{H}_{6} \mathrm{O}\right)+\mathrm{He}$ & $3.5 \times 10^{-26}$ \\
\hline $\mathrm{C}_{2} \mathrm{H}_{4} \mathrm{O}_{2} \mathrm{H}^{+}\left(\mathrm{H}_{2} \mathrm{O}\right)+\mathrm{C}_{3} \mathrm{H}_{6} \mathrm{O} \rightarrow \mathrm{C}_{3} \mathrm{H}_{6} \mathrm{OH}^{+} \mathrm{C}_{2} \mathrm{H}_{4} \mathrm{O}_{2}+\mathrm{H}_{2} \mathrm{O}$ & $2.45 \times 10^{-9}$ \\
\hline $\mathrm{C}_{2} \mathrm{H}_{4} \mathrm{O}_{2} \mathrm{H}^{+}\left(\mathrm{H}_{2} \mathrm{O}\right)+\mathrm{C}_{3} \mathrm{H}_{6} \mathrm{O} \rightarrow \mathrm{C}_{3} \mathrm{H}_{6} \mathrm{OH}^{+}\left(\mathrm{H}_{2} \mathrm{O}\right)+\mathrm{C}_{2} \mathrm{H}_{4} \mathrm{O}_{2}$ & $3.5 \times 10^{-10}$ \\
\hline $\mathrm{C}_{2} \mathrm{H}_{4} \mathrm{O}_{2} \mathrm{H}^{+}\left(\mathrm{H}_{2} \mathrm{O}\right)_{2}+\mathrm{C}_{3} \mathrm{H}_{6} \mathrm{O} \rightarrow \mathrm{C}_{2} \mathrm{H}_{4} \mathrm{O}_{2} \mathrm{H}^{+}\left(\mathrm{H}_{2} \mathrm{O}\right)\left(\mathrm{C}_{3} \mathrm{H}_{6} \mathrm{O}\right)+\mathrm{H}_{2} \mathrm{O}$ & $1 \times 10^{-10}$ \\
\hline $\mathrm{C}_{2} \mathrm{H}_{4} \mathrm{O}_{2} \mathrm{H}^{+}\left(\mathrm{H}_{2} \mathrm{O}\right)_{2}+\mathrm{C}_{3} \mathrm{H}_{6} \mathrm{O} \rightarrow \mathrm{C}_{3} \mathrm{H}_{6} \mathrm{OH}^{+} \mathrm{C}_{2} \mathrm{H}_{4} \mathrm{O}_{2}+2 \mathrm{H}_{2} \mathrm{O}$ & $1.2 \times 10^{-9}$ \\
\hline $\mathrm{C}_{3} \mathrm{H}_{6} \mathrm{OH}^{+}\left(\mathrm{H}_{2} \mathrm{O}\right)+\mathrm{C}_{3} \mathrm{H}_{6} \mathrm{O} \rightarrow \mathrm{C}_{3} \mathrm{H}_{6} \mathrm{OH}^{+}\left(\mathrm{C}_{3} \mathrm{H}_{6} \mathrm{O}\right)+\mathrm{H}_{2} \mathrm{O}$ & $1.8 \times 10^{-9}$ \\
\hline $\mathrm{C}_{3} \mathrm{H}_{6} \mathrm{OH}^{+} \mathrm{C}_{2} \mathrm{H}_{4} \mathrm{O}_{2}+\mathrm{C}_{3} \mathrm{H}_{6} \mathrm{O} \rightarrow \mathrm{C}_{3} \mathrm{H}_{6} \mathrm{OH}^{+}\left(\mathrm{C}_{3} \mathrm{H}_{6} \mathrm{O}\right)+\mathrm{C}_{2} \mathrm{H}_{4} \mathrm{O}_{2}$ & $1.8 \times 10^{-9}$ \\
\hline $\mathrm{C}_{2} \mathrm{H}_{4} \mathrm{O}_{2} \mathrm{H}^{+}+\mathrm{C}_{3} \mathrm{H}_{6} \mathrm{O}+\mathrm{He} \rightarrow \mathrm{C}_{3} \mathrm{H}_{6} \mathrm{OH}^{+} \mathrm{C}_{2} \mathrm{H}_{4} \mathrm{O}_{2}+\mathrm{He}$ & $2.2 \times 10^{-27}$ \\
\hline $\mathrm{C}_{2} \mathrm{H}_{4} \mathrm{O}_{2} \mathrm{H}^{+}\left(\mathrm{H}_{2} \mathrm{O}\right)+\mathrm{C}_{3} \mathrm{H}_{6} \mathrm{O} \rightarrow \mathrm{C}_{3} \mathrm{H}_{6} \mathrm{OH}^{+}+\mathrm{C}_{2} \mathrm{H}_{4} \mathrm{O}_{2}\left(\mathrm{H}_{2} \mathrm{O}\right)$ & $1 \times 10^{-10}$ \\
\hline $\mathrm{C}_{2} \mathrm{H}_{4} \mathrm{O}_{2} \mathrm{H}^{+}\left(\mathrm{H}_{2} \mathrm{O}\right)+\mathrm{C}_{3} \mathrm{H}_{6} \mathrm{O}+\mathrm{He} \rightarrow \mathrm{C}_{2} \mathrm{H}_{4} \mathrm{O}_{2} \mathrm{H}^{+}\left(\mathrm{H}_{2} \mathrm{O}\right)\left(\mathrm{C}_{3} \mathrm{H}_{6} \mathrm{O}\right)+\mathrm{He}$ & $2.15 \times 10^{-28}$ \\
\hline $\mathrm{C}_{2} \mathrm{H}_{4} \mathrm{O}_{2} \mathrm{H}^{+}\left(\mathrm{H}_{2} \mathrm{O}\right)\left(\mathrm{C}_{3} \mathrm{H}_{6} \mathrm{O}\right)+\mathrm{C}_{3} \mathrm{H}_{6} \mathrm{O} \rightarrow \mathrm{C}_{3} \mathrm{H}_{6} \mathrm{OH}^{+} \mathrm{C}_{2} \mathrm{H}_{4} \mathrm{O}_{2}+\mathrm{H}_{2} \mathrm{O}+\mathrm{C}_{3} \mathrm{H}_{6} \mathrm{O}$ & $2 \times 10^{-9}$ \\
\hline
\end{tabular}


Table S3. Solution 2 - direct formation of $m / z 77$ and $m / z 119$ with rapid formation of $m / z 137$

\begin{tabular}{|l|l|}
\hline Reaction & Rate coefficient \\
\hline $\mathrm{C}_{2} \mathrm{H}_{4} \mathrm{O}_{2} \mathrm{H}^{+}+\mathrm{C}_{3} \mathrm{H}_{6} \mathrm{O} \rightarrow \mathrm{C}_{3} \mathrm{H}_{6} \mathrm{OH}^{+}+\mathrm{C}_{2} \mathrm{H}_{4} \mathrm{O}_{2}$ & $2 \times 10^{-9}$ \\
\hline $\mathrm{C}_{3} \mathrm{H}_{6} \mathrm{OH}^{+}+\mathrm{C}_{3} \mathrm{H}_{6} \mathrm{O}+\mathrm{He} \rightarrow \mathrm{C}_{3} \mathrm{H}_{6} \mathrm{OH}^{+}\left(\mathrm{C}_{3} \mathrm{H}_{6} \mathrm{O}\right)+\mathrm{He}$ & $3.5 \times 10^{-26}$ \\
\hline $\mathrm{C}_{2} \mathrm{H}_{4} \mathrm{O}_{2} \mathrm{H}^{+}\left(\mathrm{H}_{2} \mathrm{O}\right)+\mathrm{C}_{3} \mathrm{H}_{6} \mathrm{O} \rightarrow \mathrm{C}_{3} \mathrm{H}_{6} \mathrm{OH}^{+} \mathrm{C}_{2} \mathrm{H}_{4} \mathrm{O}_{2}+\mathrm{H}_{2} \mathrm{O}$ & $2.45 \times 10^{-9}$ \\
\hline $\mathrm{C}_{2} \mathrm{H}_{4} \mathrm{O}_{2} \mathrm{H}^{+}\left(\mathrm{H}_{2} \mathrm{O}\right)+\mathrm{C}_{3} \mathrm{H}_{6} \mathrm{O} \rightarrow \mathrm{C}_{3} \mathrm{H}_{6} \mathrm{OH}^{+}\left(\mathrm{H}_{2} \mathrm{O}\right)+\mathrm{C}_{2} \mathrm{H}_{4} \mathrm{O}_{2}$ & $3.5 \times 10^{-10}$ \\
\hline $\mathrm{C}_{2} \mathrm{H}_{4} \mathrm{O}_{2} \mathrm{H}^{+}\left(\mathrm{H}_{2} \mathrm{O}\right)_{2}+\mathrm{C}_{3} \mathrm{H}_{6} \mathrm{O} \rightarrow \mathrm{C}_{2} \mathrm{H}_{4} \mathrm{O}_{2} \mathrm{H}^{+}\left(\mathrm{H}_{2} \mathrm{O}\right)\left(\mathrm{C}_{3} \mathrm{H}_{6} \mathrm{O}\right)+\mathrm{H}_{2} \mathrm{O}$ & $1.3 \times 10^{-9}$ \\
\hline $\mathrm{C}_{3} \mathrm{H}_{6} \mathrm{OH}^{+}\left(\mathrm{H}_{2} \mathrm{O}\right)+\mathrm{C}_{3} \mathrm{H}_{6} \mathrm{O} \rightarrow \mathrm{C}_{3} \mathrm{H}_{6} \mathrm{OH}^{+}\left(\mathrm{C}_{3} \mathrm{H}_{6} \mathrm{O}\right)+\mathrm{H}_{2} \mathrm{O}$ & $1.8 \times 10^{-9}$ \\
\hline $\mathrm{C}_{3} \mathrm{H}_{6} \mathrm{OH}^{+} \mathrm{C}_{2} \mathrm{H}_{4} \mathrm{O}_{2}+\mathrm{C}_{3} \mathrm{H}_{6} \mathrm{O} \rightarrow \mathrm{C}_{3} \mathrm{H}_{6} \mathrm{OH}^{+}\left(\mathrm{C}_{3} \mathrm{H}_{6} \mathrm{O}\right)+\mathrm{C}_{2} \mathrm{H}_{4} \mathrm{O}_{2}$ & $1.8 \times 10^{-9}$ \\
\hline $\mathrm{C}_{2} \mathrm{H}_{4} \mathrm{O}_{2} \mathrm{H}^{+}+\mathrm{C}_{3} \mathrm{H}_{6} \mathrm{O}+\mathrm{He} \rightarrow \mathrm{C}_{3} \mathrm{H}_{6} \mathrm{OH}^{+} \mathrm{C}_{2} \mathrm{H}_{4} \mathrm{O}_{2}+\mathrm{He}_{2}$ & $2.2 \times 10^{-27}$ \\
\hline $\mathrm{C}_{2} \mathrm{H}_{4} \mathrm{O}_{2} \mathrm{H}^{+}\left(\mathrm{H}_{2} \mathrm{O}\right)+\mathrm{C}_{3} \mathrm{H}_{6} \mathrm{O} \rightarrow \mathrm{C}_{3} \mathrm{H}_{6} \mathrm{OH}^{+}+\mathrm{C}_{2} \mathrm{H}_{4} \mathrm{O}_{2}\left(\mathrm{H}_{2} \mathrm{O}\right)$ & $1 \times 10^{-10}$ \\
\hline $\mathrm{C}_{2} \mathrm{H}_{4} \mathrm{O}_{2} \mathrm{H}^{+}\left(\mathrm{H}_{2} \mathrm{O}\right)+\mathrm{C}_{3} \mathrm{H}_{6} \mathrm{O}+\mathrm{He}_{2} \rightarrow \mathrm{C}_{2} \mathrm{H}_{4} \mathrm{O}_{2} \mathrm{H}^{+}\left(\mathrm{H}_{2} \mathrm{O}\right)\left(\mathrm{C}_{3} \mathrm{H}_{6} \mathrm{O}\right)+\mathrm{He}$ & $2.15 \times 10^{-28}$ \\
\hline $\mathrm{C}_{2} \mathrm{H}_{4} \mathrm{O}_{2} \mathrm{H}^{+}\left(\mathrm{H}_{2} \mathrm{O}\right)\left(\mathrm{C}_{3} \mathrm{H}_{6} \mathrm{O}\right) \rightarrow \mathrm{C}_{3} \mathrm{H}_{6} \mathrm{OH}^{+} \mathrm{C}_{2} \mathrm{H}_{4} \mathrm{O}_{2}+\mathrm{H}_{2} \mathrm{O}$ & 20000 \\
\hline
\end{tabular}

Table S4. Solution 3 - formation of $m / z 77$ and $m / z 119$ via $m / z 137$ ion

\begin{tabular}{|l|l|}
\hline Reaction & Rate coefficient \\
\hline $\mathrm{C}_{2} \mathrm{H}_{4} \mathrm{O}_{2} \mathrm{H}^{+}+\mathrm{C}_{3} \mathrm{H}_{6} \mathrm{O} \rightarrow \mathrm{C}_{3} \mathrm{H}_{6} \mathrm{OH}^{+}+\mathrm{C}_{2} \mathrm{H}_{4} \mathrm{O}_{2}$ & $2 \times 10^{-9}$ \\
\hline $\mathrm{C}_{3} \mathrm{H}_{6} \mathrm{OH}^{+}+\mathrm{C}_{3} \mathrm{H}_{6} \mathrm{O}+\mathrm{He} \rightarrow \mathrm{C}_{3} \mathrm{H}_{6} \mathrm{OH}^{+}\left(\mathrm{C}_{3} \mathrm{H}_{6} \mathrm{O}\right)+\mathrm{He}$ & $3.5 \times 10^{-26}$ \\
\hline $\mathrm{C}_{2} \mathrm{H}_{4} \mathrm{O}_{2} \mathrm{H}^{+}\left(\mathrm{H}_{2} \mathrm{O}\right)_{2}+\mathrm{C}_{3} \mathrm{H}_{6} \mathrm{O} \rightarrow \mathrm{C}_{2} \mathrm{H}_{4} \mathrm{O}_{2} \mathrm{H}^{+}\left(\mathrm{H}_{2} \mathrm{O}\right)\left(\mathrm{C}_{3} \mathrm{H}_{6} \mathrm{O}\right)+\mathrm{H}_{2} \mathrm{O}$ & $1.3 \times 10^{-9}$ \\
\hline $\mathrm{C}_{3} \mathrm{H}_{6} \mathrm{OH}^{+}\left(\mathrm{H}_{2} \mathrm{O}\right)+\mathrm{C}_{3} \mathrm{H}_{6} \mathrm{O} \rightarrow \mathrm{C}_{3} \mathrm{H}_{6} \mathrm{OH}^{+}\left(\mathrm{C}_{3} \mathrm{H}_{6} \mathrm{O}\right)+\mathrm{H}_{2} \mathrm{O}$ & $1.8 \times 10^{-9}$ \\
\hline $\mathrm{C}_{3} \mathrm{H}_{6} \mathrm{OH}^{+} \mathrm{C}_{2} \mathrm{H}_{4} \mathrm{O}_{2}+\mathrm{C}_{3} \mathrm{H}_{6} \mathrm{O} \rightarrow \mathrm{C}_{3} \mathrm{H}_{6} \mathrm{OH}^{+}\left(\mathrm{C}_{3} \mathrm{H}_{6} \mathrm{O}\right)+\mathrm{C}_{2} \mathrm{H}_{4} \mathrm{O}_{2}$ & $1.8 \times 10^{-9}$ \\
\hline $\mathrm{C}_{2} \mathrm{H}_{4} \mathrm{O}_{2} \mathrm{H}^{+}+\mathrm{C}_{3} \mathrm{H}_{6} \mathrm{O}+\mathrm{He} \rightarrow \mathrm{C}_{3} \mathrm{H}_{6} \mathrm{OH}^{+} \mathrm{C}_{2} \mathrm{H}_{4} \mathrm{O}_{2}+\mathrm{He}$ & $2.2 \times 10^{-27}$ \\
\hline $\mathrm{C}_{2} \mathrm{H}_{4} \mathrm{O}_{2} \mathrm{H}^{+}\left(\mathrm{H}_{2} \mathrm{O}\right)+\mathrm{C}_{3} \mathrm{H}_{6} \mathrm{O} \rightarrow \mathrm{C}_{3} \mathrm{H}_{6} \mathrm{OH}^{+}+\mathrm{C}_{2} \mathrm{H}_{4} \mathrm{O}_{2}\left(\mathrm{H}_{2} \mathrm{O}\right)$ & $1 \times 10^{-10}$ \\
\hline $\mathrm{C}_{2} \mathrm{H}_{4} \mathrm{O}_{2} \mathrm{H}^{+}\left(\mathrm{H}_{2} \mathrm{O}\right)+\mathrm{C}_{3} \mathrm{H}_{6} \mathrm{O}+\mathrm{He}_{2} \rightarrow \mathrm{C}_{2} \mathrm{H}_{4} \mathrm{O}_{2} \mathrm{H}^{+}\left(\mathrm{H}_{2} \mathrm{O}\right)\left(\mathrm{C}_{3} \mathrm{H}_{6} \mathrm{O}\right)+\mathrm{He}$ & $6 \times 10^{-26}$ \\
\hline $\mathrm{C}_{2} \mathrm{H}_{4} \mathrm{O}_{2} \mathrm{H}^{+}\left(\mathrm{H}_{2} \mathrm{O}\right)\left(\mathrm{C}_{3} \mathrm{H}_{6} \mathrm{O}\right) \rightarrow \mathrm{C}_{3} \mathrm{H}_{6} \mathrm{OH}^{+} \mathrm{C}_{2} \mathrm{H}_{4} \mathrm{O}_{2}+\mathrm{H}_{2} \mathrm{O}$ & 250000 \\
\hline $\mathrm{C}_{2} \mathrm{H}_{4} \mathrm{O}_{2} \mathrm{H}^{+}\left(\mathrm{H}_{2} \mathrm{O}\right)\left(\mathrm{C}_{3} \mathrm{H}_{6} \mathrm{O}\right) \rightarrow \mathrm{C}_{3} \mathrm{H}_{6} \mathrm{OH}^{+}\left(\mathrm{H}_{2} \mathrm{O}\right)+\mathrm{C}_{2} \mathrm{H}_{4} \mathrm{O}_{2}$ & 35000 \\
\hline
\end{tabular}

